\title{
Selective Alteration of Long-Term Potentiation-Induced Transcriptional Response in Hippocampus of Aged, Memory- Impaired Rats
}

\author{
Anthony Lanahan, ${ }^{1}$ Gregory Lyford, ${ }^{1}$ Gail S. Stevenson, ${ }^{5}$ Paul F. Worley, ${ }^{1,2}$ and Carol A. Barnes ${ }^{3,4,5}$ \\ Departments of ${ }^{1}$ Neuroscience and ${ }^{2}$ Neurology, Johns Hopkins University School of Medicine, Baltimore, Maryland \\ 21205-2185, and Departments of ${ }^{3}$ Psychology and ${ }^{4}$ Neurology, and ${ }^{5}$ Division of Neural Systems, Memory and Aging, \\ University of Arizona, Tucson, Arizona 85424
}

\begin{abstract}
Normal human aging is associated with selective changes in cognition that are attributable, in part, to dysfunction of hippocampal pathways. Rodents also exhibit age-dependent hippocampal dysfunction that results in spatial memory deficits and a correlated reduction in the maintenance of long-term potentiation (LTP). Although suprathreshold stimulus protocols result in normal LTP induction in aged rats, the ability to sustain this increase in synaptic efficacy is reduced in the old animals. The maintenance phase of LTP is known to be dependent on rapid, transcriptional events, and recent studies have identified signal transduction mechanisms that link glutamate-induced responses at the synapse with transcriptional responses at the nucleus. To examine the integrity of these signaling pathways in aged hippocampus, we monitored the induction of a panel of immediate early genes (IEGs) that are known to be transcrip-
\end{abstract}

tionally activated after LTP-inducing stimuli, using a "reverse Northern" strategy. Here we report that a broad representation of IEGs are similarly induced in awake, behaving young adult and aged, memory-impaired rats. This indicates a general preservation of these presumptive signaling pathways during the aging process. Induced levels of c-fos mRNA, however, are significantly higher in the aged animals. These observations suggest that age-dependent hippocampal dysfunction may be associated with a selective change in the dynamic activity of signaling pathways upstream of c-fos, possibly involving calcium regulation.

Key words: long-term potentiation (LTP); immediate early gene; aging; reverse Northern; age-dependent memory decline; transcription; protein synthesis inhibitor
Rodents exhibit an age-dependent impairment of spatial learning that is correlated with a deficit in the maintenance of hippocampal long-term potentiation (LTP) (Bliss and Lomo, 1973; Barnes, 1979; Barnes and McNaughton, 1980, 1985; de Toledo-Morrell et al., 1988). The aging process is not associated, however, with defective LTP induction mechanisms, even when the same suprathreshold stimulus induction protocols are used that produce LTP decay deficits (Landfield and Lynch, 1977; Landfield et al., 1978; Barnes, 1979; Barnes and McNaughton, 1980; Deupree et al., 1991; Moore et al., 1993; Barnes et al., 1996; but see Tielen et al., 1983; Hori et al., 1992; Lynch and Voss, 1994). Studies examining the molecular basis of the maintenance or late phase of long-term synaptic plasticity indicate an essential role for induced mRNA and protein synthesis during a brief time after the conditioning stimulus (Flexner et al., 1963; Agranoff, 1981; Davis and Squire, 1984; Montarolo et al., 1986; Nguyen et al., 1994; Tully et al., 1994). Several genes have been identified that are rapidly induced in association with LTP in the rodent hippocampus and include transcription factors (Douglas et al., 1988; Cole et al., 1989; Dragunow et al., 1989; Worley et al., 1993; Yamagata et al., 1994a), growth factors (Gall and Lauterborn, 1992; Andreasson

Received Oct. 9, 1996; revised Jan. 17, 1997; accepted Jan. 31, 1997.

This work was supported by Public Health Service Grants AG09219 (C.B., P.W.), MH01152 (P.W.), and MH01227 (C.B.). We thank L. Church and G. Rao for assistance with these experiments.

Correspondence should be addressed to Dr. P. F. Worley, Department of Neuroscience, Johns Hopkins University School of Medicine, 725 N. Wolfe Street, Baltimore, MD 21205-2185.

Copyright (C) 1997 Society for Neuroscience $\quad 0270-6474 / 97 / 172876-10 \$ 05.00 / 0$ and Worley, 1995; Thoenen, 1995; Tsui et al., 1996), and a secreted serine protease (Qian et al., 1993), as well as enzymes involved in signal transduction (Yamagata et al., 1993, 1994b). The stimulus-dependent transcriptional induction of these genes is presumed to involve convergent signal transduction pathways. For example, analysis of the c-fos promoter in transgenic mice indicates a requirement for four distinct regulatory elements for its tissue- and stimulus-specific expression in brain (Robertson et al., 1995). Glutamate receptor activation results in rapid phosphorylation events that modify the activity of at least two transcription regulatory factors: serum response factor (SRF) and cAMP response element binding protein (CREB) (Bading et al., 1993). These dynamic processes are presumed to confer specificity of response to the LTP-inducing stimulus.

A primary question examined in the present experiment is whether alterations in signal transduction mechanisms could potentially contribute to memory deficits observed in old animals. Consistent with this hypothesis is the observation that the agedependent decrease in LTP maintenance is not detectable for several days after robust induction protocols. The emergence of the age deficit at long time intervals argues strongly for mechanisms requiring macromolecular synthesis, because in all systems examined to date, LTP lasting $>24 \mathrm{hr}$ requires such synthesis. Moreover, in a number of systems, aging is known to be associated with changes in transcriptional mechanisms that result in altered cellular responses to tissue-specific signals (Ammendola et al., 1992; Riabowol et al., 1992; Supakar et al., 1993; Sutin et al., 1993; Stein and Vjekoslov, 1995). To examine the hypothesis that agedependent memory decline results from alterations in signaling 
pathways linking the initial NMDA-dependent response with subsequent transcriptional events, we have used a panel of immediate early genes (IEGs) that are known to be rapidly induced by LTP stimulation as a "read out" of glutamate-induced signal transduction. Because individual IEGs possess distinct combinations of promoter-enhancer elements, the analysis of multiple IEGs is anticipated to increase the likelihood of detecting age-dependent changes in signaling. Using a panel of 19 IEGs, we report that the IEG induction remains robust in the hippocampus of aged rats in response to a stimulus that induces LTP; however, induced levels of c-fos mRNA are significantly higher in the aged animals. This observation implicates specific signaling pathways "upstream" of c-fos in age-dependent hippocampal dysfunction.

\section{MATERIALS AND METHODS}

Behavioral testing and stimulation protocols. Two age groups of male F-344 retired breeder rats were obtained from Charles River Laboratories at 9 and 26 months, respectively. When they were killed, the rats were $10(n=$ $14)$ and $27(n=11)$ months, respectively. The Morris swim task (Morris, 1981) was used to test spatial and visual discrimination ability (procedure described in detail in Shen and Barnes, 1996). For the spatial version of the task, the escape platform was submersed under the opaque water surface in a fixed location, and rats were given 24 trials over 4 consecutive days. For the visual cue version, the platform was extended $2 \mathrm{~cm}$ above the surface of the water and was moved randomly between one of four locations in the pool after each trial, for a total of six trials over $1 \mathrm{~d}$. The behavior of the rats was tracked by computer (HVS Image), and analysis was accomplished off-line.

Behaviorally tested rats were then implanted surgically with recording electrodes [114 $\mu \mathrm{m}$ Teflon-coated stainless steel (Medwire Corp.)] in the hilus of the fascia dentata, and stimulating electrodes were implanted in the perforant pathway for chronic bilateral in vivo recordings of hippocampal population responses (Barnes and McNaughton, 1985). Rats were given at least 1 week recovery before electrophysiological testing and were adapted to the recording procedure daily for at least 1 week before the high-frequency (HF) stimulation treatment. One hour before experiment initiation, rats were injected with cycloheximide $(50 \mathrm{mg} / \mathrm{kg}$, i.p.). One hemisphere received low-frequency (LF) test stimulation (500 $\mu \mathrm{A}$ diphasic square wave stimuli delivered at $0.1 \mathrm{~Hz}$ ), which does not alter the amplitude of the evoked responses, and the contralateral hemisphere received HF stimulation (13 repetitions of a $25 \mathrm{msec}, 500 \mu \mathrm{A}$ stimulus train, delivered at $400 \mathrm{~Hz}$, overall repetition $1 / 15 \mathrm{~min}$ ), which induced LTP. Fifteen minutes after the last HF stimulus burst, brains were removed, and the fascia dentata was dissected from the hippocampus. The anterior two thirds and posterior one third of the fascia dentata were processed separately.

Control rats $(n=3 ; 4$ months) were similarly pretreated with cycloheximide and received a maximal electroconvulsive seizure (MECS) from an electroconvulsive therapy (ECT) unit (Ugo Basile), as described previously (Worley et al., 1993), every $30 \mathrm{~min}$ for a total of eight stimuli. The ECT unit is a current generator that connects to the rat with nontraumatic ear clips and is set to deliver a $1 \mathrm{sec}$ pulse with a frequency of $100 \mathrm{~Hz}$, a pulse width of $0.5 \mathrm{msec}$, and a current of $80 \mathrm{~mA}$. MECS produces a tonic seizure with extension of the hindlimbs that lasts for $\sim 15$ $\mathrm{sec}$ and is followed by recovery of consciousness within $\sim 1-2 \mathrm{~min}$. Rats were killed $15 \mathrm{~min}$ after the last MECS. The naive controls did not receive cycloheximide.

"Reverse Northern" analysis. Plasmids containing the indicated cDNAs were linearized with the appropriate restriction enzymes, and $1 \mu \mathrm{g}$ of each plasmid was loaded per lane and electrophoresed in $1 \%$ agarose gels. Several identical gels were prepared and after denaturation and neutralization were transferred to nitrocellulose. $\operatorname{Poly}\left(\mathrm{A}^{+}\right) \mathrm{RNA}$ was isolated from individual samples using micro Fastrack (Invitrogen, San Diego, CA), and nonradioactive double-stranded cDNA was synthesized using an oligo dT primer with Superscript reverse transcriptase (Life Technologies, Gaithersburg, MD) according to the manufacturer's protocol. Briefly, $5 \mu \mathrm{g}$ of poly $\left(\mathrm{A}^{+}\right) \mathrm{RNA}$ was mixed with $1 \mu \mathrm{g}$ of an oligo dT primer, heated at $70^{\circ} \mathrm{C}$ for $10 \mathrm{~min}$, and cooled on ice. First-strand cDNA was synthesized in the presence of $50 \mathrm{~mm}$ Tris, $\mathrm{pH} 8.3,7.5 \mathrm{~mm} \mathrm{KCl}, 3 \mathrm{~mm}$ $\mathrm{MgCl}_{2}, 10 \mathrm{~mm}$ dithiothreitol (DTT), $500 \mu \mathrm{M}$ of each dNTP, $1 \mathrm{U} / \mu \mathrm{l}$ RNasin (Promega, Madison, WI), and $1000 \mathrm{U}$ of SuperScript Reverse Transcriptase (Life Technologies). The final reaction mix of $20 \mu \mathrm{l}$ was incubated at $40^{\circ} \mathrm{C}$ for $60 \mathrm{~min}$. The single-stranded cDNA was converted to double-stranded by incubating at $16^{\circ} \mathrm{C}$ for $2 \mathrm{hr}$ in the presence of 25 mM Tris, pH 7.5, $100 \mathrm{~mm} \mathrm{KCl,} 5 \mathrm{~mm} \mathrm{MgCl}, 10 \mathrm{~mm}\left(\mathrm{NH}_{4}\right)_{2} \mathrm{SO}_{4}, 0.15 \mathrm{~mm}$ $\mathrm{B}-\mathrm{NAD}+, 250 \mu \mathrm{M}$ of each dNTP, $1.2 \mathrm{mM}$ DTT, $65 \mathrm{U} / \mathrm{ml}$ Escherichia coli DNA Ligase, $250 \mathrm{U} / \mathrm{ml}$ DNA polymerase I, and $13 \mathrm{U} / \mathrm{ml}$ RNase; the final reaction volume was $150 \mu \mathrm{l}$. The reaction was terminated by adding EDTA to $20 \mathrm{~mm}$, and the reaction was extracted with phenol and precipitated with ethanol in the presence of $100 \mu \mathrm{g}$ of glycogen. The precipitated cDNA mix was then chromatographed over a NICK column (Pharmacia, Piscataway, NJ) and reprecipitated in the presence of glycogen $(100 \mu \mathrm{g})$ to remove free nucleotides that might hamper the $\left.{ }^{32} \mathrm{P}\right] \mathrm{dCTP}$ radiolabeling of the cDNA. cDNA was radiolabeled by random priming (Pharmacia) with $\left[{ }^{32} \mathrm{P}\right] \mathrm{dCTP}(\mathrm{NEN})$ to a specific activity of $>10^{9} \mathrm{cpm} / \mu \mathrm{g}$. Identical blots were prehybridized overnight at $68^{\circ} \mathrm{C}$ in $5 \times$ SSC, $5 \times$ Denhardt's solution, $10 \mathrm{~mm}$ EDTA, $0.2 \%$ SDS, $50 \mathrm{~mm} \mathrm{NaPO}$, $\mathrm{pH} 7.0$, and $100 \mu \mathrm{g} / \mathrm{ml}$ boiled, sonicated salmon sperm DNA. Blots were then hybridized overnight in freshly prepared hybridization solution containing $1 \times 10^{6} \mathrm{cpm} / \mathrm{ml}$ of the appropriate ${ }^{32} \mathrm{P}$-labeled cDNA probe (Lanahan et al., 1992). Filters were washed at room temperature in $2 \times$ SSC, $0.2 \%$ SDS, and then in $0.2 \times \mathrm{SSC}, 0.2 \%$ SDS at $68^{\circ} \mathrm{C}$. Filters were then exposed to $\mathrm{x}$-ray film with an intensifier screen at $-80^{\circ} \mathrm{C}$ for $1-3 \mathrm{~d}$. Several of the IEGs used in this panel are novel and were identified by differential screening of cDNA libraries prepared from MECS-stimulated hippocampus as described previously (Yamagata et al., 1993). Blotted cDNAs included (genes that are rapidly regulated in brain by depolarizing stimuli are underlined, and the reference describes their regulation in brain): glyceraldehyde phosphate dehydrogenase (GAPD); $\beta$-tubulin, c-fos (Morgan et al., 1987); fos B (Worley et al., 1993); c-jun (Saffen et al., 1988); c-myc; cox-1 (noninducible cyclooxygenase); cox-2 (inducible cyclooxygenase; Yamagata et al., 1993); \#8 (novel cDNA); \#68 (novel cDNA); glucose 6 phosphate dehydrogenase (G6PD); zif268 (Saffen et al., 1988); Krox 20 (Worley et al., 1993); $\beta$-A activin (Andreasson and Worley, 1995); Rheb (Ras homolog enriched in brain; Yamagata et al., 1994b); Narp (neuronal activity-regulated pentraxin; Tsui et al., 1996); \#108 (identical to Egr 3) (Yamagata et al., 1994a); \#59 (novel clone); Egr 3 (Yamagata et al., 1994a); $\beta$-actin, Bluescript cloning vector (Stratagene, La Jolla, CA); Fra-1 (Fos-related antigen Fra-1); jun B (Saffen et al., 1988); nur 77 (Worley et al., 1993); GDF-1 (glial-derived factor 1); ciliary neurotrophic factor (CNTF) (Gall and Lauterborn, 1992); $\gamma$-actin; activity-regulated cytoskeleton-associated protein ( $\operatorname{Arc}$; Lyford et al., 1995); \#62 (novel clone); histone 3.3 (unpublished observation). Autoradiographic images were obtained by exposure of the blots to $\mathrm{x}$-ray film with an intensifier screen at $-80^{\circ} \mathrm{C}$ for $12-72 \mathrm{hr}$. Levels of hybridization were quantitated using a phosphorimager (Molecular Dynamics, Sunnyvale, CA) and normalized to the noninducible gene GAPD.

Statistical analyses. For the behavioral analyses, two-way ANOVAs were used to test the main effects of age and trials (the latter to determine whether each group learned the tasks). For the comparisons of mRNA levels, two-way ANOVAs were used to test the main effects of age (AGE) and stimulation (STIM) and the interaction of AGE $\times$ STIM.

\section{RESULTS}

\section{Reverse Northern analysis of multiple IEGs in small tissue samples}

To compare induced mRNA levels in adult and aged rats in response to an LTP-inducing stimulus, it is experimentally advantageous to be able to assess responses in individual hippocampi. We therefore examined the feasibility of using a reverse Northern strategy. With this technique, levels of tissue mRNA are assessed by monitoring the intensity of hybridization signal of radiolabeled cDNA prepared from tissue RNA to Southern blots containing cloned cDNAs of multiple candidate IEGs (Lanahan et al., 1992). The hybridization signal for each gene is indicative of the tissue mRNA level, and data analysis is similar to that of a conventional Northern in which cloned cDNA inserts are radiolabeled and hybridized to sized tissue RNA.

A critical step for the reverse Northern technique is the conversion of RNA to cDNA. This step is important both from the standpoint of obtaining sufficient material from small tissue samples and for achieving labeled probe that is representative of tissue mRNA levels. We prepared poly $\left(\mathrm{A}^{+}\right)$mRNA from individ- 


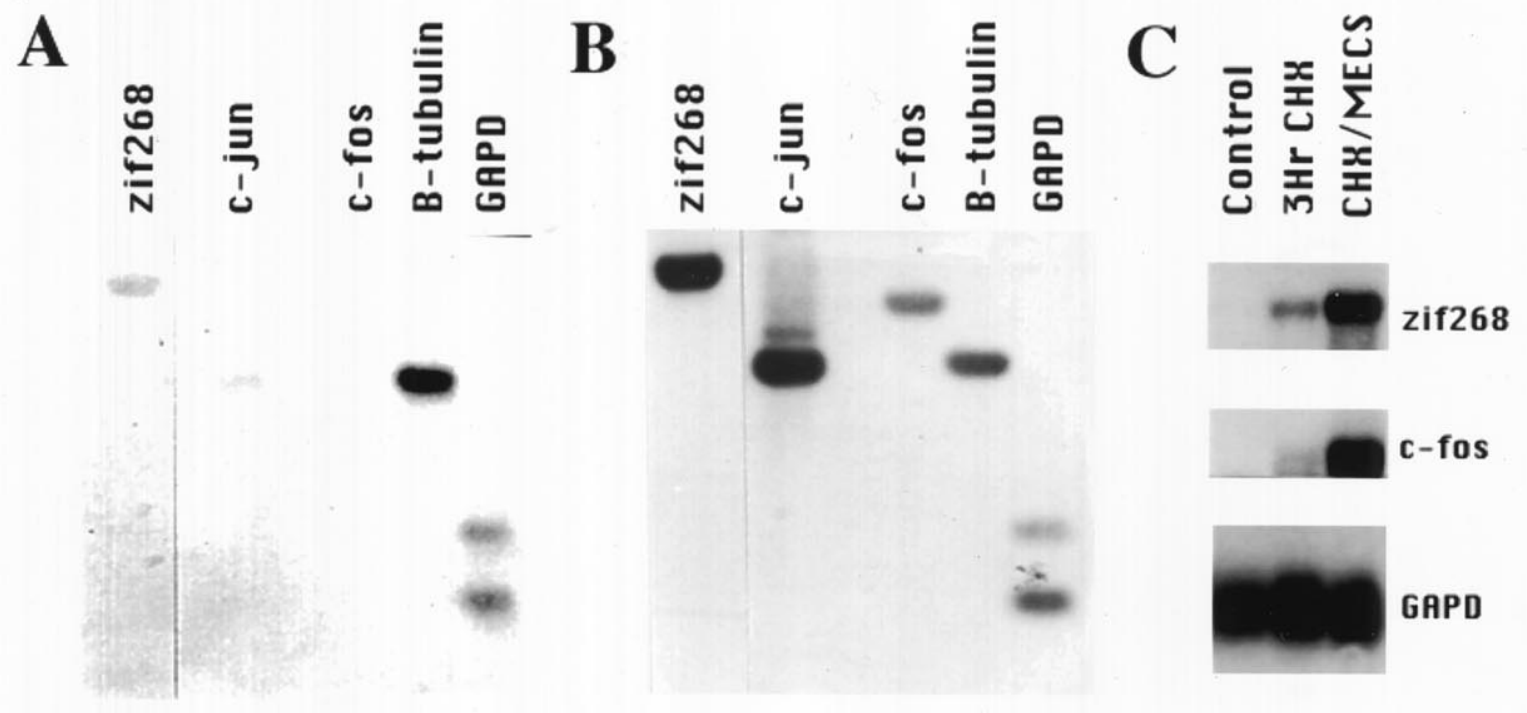

Figure 1. "Reverse northern" analysis of IEG induction by seizure. Duplicate Southern blots were probed with radiolabeled cDNA prepared from hippocampus of naive control $(A)$ and MECS with cycloheximide-stimulated $(B)$ rats. $\beta$-Tubulin and GAPD are constitutively expressed and provide a comparison for genes that are induced by MECS. Comparison of blots $A$ and $B$ demonstrate that MECS increases the intensity of hybridization to zif 268 , c-jun, and c-fos. $C$, Blots demonstrate a conventional Northern analysis of $2 \mu \mathrm{g}$ Poly $\left(\mathrm{A}^{+}\right) \mathrm{RNA}$ prepared from hippocampus of naive control rats, rats treated with cycloheximide for $3 \mathrm{hr}\left({ }^{3} \mathrm{Hr} C H X\right)$, or cycloheximide in combination with MECS $(C H X / M E C S)$ and probed with zif 268, c-fos, and GAPD. The sensitivity of the reverse Northern is comparable to conventional Northern methods and permits analysis of multiple genes from small tissue samples.

ually dissected hippocampi and were routinely able to convert $\sim 30 \%$ of poly $\left(\mathrm{A}^{+}\right) \mathrm{RNA}$ to first-strand cDNA. Copying the second strand of cDNA doubled this yield. Because the yield of poly $\left(\mathrm{A}^{+}\right) \mathrm{RNA}$ from a single hippocampus is typically $\sim 1 \mu \mathrm{g}$, we are able to prepare $\sim 600 \mathrm{ng}$ of cDNA from a single hippocampus. To use this cDNA for differential Southern analysis, cDNA is labeled by random priming, which achieves a specific activity of $\sim 2 \times 10^{9} \mathrm{dpm} / \mu \mathrm{g}$ cDNA. Approximately $50 \mathrm{ng}$ of cDNA is sufficient to prepare probe for a 20 lane Southern blot using standard agarose gel chromatography and solution hybridization techniques. Accordingly, a single hippocampus is more than sufficient for this analysis. Note that all of these enzymatic steps are linear with respect to the tissue RNA concentrations, which ensures that the labeled cDNA is representative of the relative abundance of each species of mRNA in the tissue. No PCR step is used in the preparation of labeled cDNA.

In Figure 1, we use the reverse Northern to compare mRNA levels in hippocampus of control rats and rats that received a maximal MECS. MECS is a simple and reliable means to induce the expression of IEGs in the hippocampus, and it produces very robust and durable potentiation of the perforant pathway-granule cell synapse (Barnes et al., 1994). In initial studies, Southern blots were prepared using a panel of three IEGs as well as representative constitutively expressed genes that serve as controls and permit comparisons between different tissues samples. Confirming previous studies that used in situ hybridization and Northern assays (Worley et al., 1993), the reverse Northern demonstrates robust inductions of each of the IEGs. Exposure times on standard film (XAR5) ranged from overnight to several days.
Parallel studies were conducted to assess the sensitivity of the reverse Northern, in which samples of the same control and MECS-stimulated RNA ( 2 mg of poly $\left(\mathrm{A}^{+}\right) \mathrm{RNA} /$ lane) were blotted and hybridized with probes for zif268 and c-fos. Robust hybridization was detected in overnight exposures to film. In this side-by-side comparison, the sensitivity of the reverse Northern appeared to be comparable to standard Northern analysis. Note, however, that the reverse Northern requires far less RNA to screen multiple genes and is therefore preferable for the present application.

\section{Analysis of LTP-induced IEG response by reverse Northern}

We devised an LTP stimulation protocol that mimics the type of repetitive stimulus that results in age-dependent differences in LTP maintenance and also optimizes detection of IEGs. Age-dependent reductions in LTP maintenance have been observed after multiple (12), daily repetitions of standard LTPinducing HF stimuli (i.e., time constant of decay for old $=17 \mathrm{~d}$, for young $=37 \mathrm{~d}$ ) (Barnes and McNaughton, 1980). By contrast, no age difference is detected after a single HF stimulation session (Barnes, 1979) in which the responses decay back to baseline within a few days. This suggests that detection of age-dependent differences in LTP decay mechanisms may require analysis of the response to multiple stimuli. Consistent with this notion, our initial studies using IEGs as probes of intracellular signaling detected no differences in the magnitude of IEG induction across age after a single LTP-inducing stimulus (Worley et al., 1993). Because IEG responses to repetitive 
Table 1. Results of two-way ANOVA of mRNA

\begin{tabular}{|c|c|c|c|c|c|c|c|c|c|c|}
\hline & \multicolumn{6}{|c|}{ Anterior hippocampus } & \multicolumn{4}{|c|}{ Posterior hippocampus } \\
\hline & \multicolumn{2}{|l|}{ Age } & \multicolumn{2}{|l|}{ STIM } & \multicolumn{2}{|c|}{ Age $\times$ STIM } & \multicolumn{2}{|l|}{ Age } & \multicolumn{2}{|l|}{ STIM } \\
\hline & $\mathrm{F}$ & $P$ & $\mathrm{~F}$ & $P$ & $\mathrm{~F}$ & $P$ & $\mathrm{~F}$ & $P$ & $\mathrm{~F}$ & $P$ \\
\hline c-fos & 9.41 & $<0.01$ & 45.25 & $<0.01$ & 6.16 & $<0.05$ & 0.03 & 0.87 & 0.07 & 0.81 \\
\hline jun $\mathrm{B}$ & 3.68 & 0.06 & 19.45 & $<0.01$ & 2.26 & 0.14 & 0.06 & 0.82 & 1.29 & 0.29 \\
\hline c-jun & 3.46 & 0.07 & 9.95 & $\leq 0.01$ & 0.29 & 0.60 & 0.18 & 0.68 & 2.36 & 0.16 \\
\hline fos $\mathrm{B}$ & 1.90 & 0.17 & 1.42 & 0.24 & - & - & 0.60 & 0.46 & 0.00 & 0.98 \\
\hline fra 1 & 0.41 & 0.53 & 1.53 & 0.22 & - & - & 0.49 & 0.50 & 0.68 & 0.43 \\
\hline zif 268 & 0.48 & 0.49 & 40.13 & $<0.01$ & 1.53 & 0.23 & - & - & - & - \\
\hline
\end{tabular}

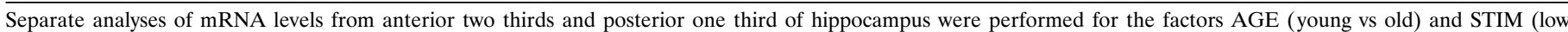

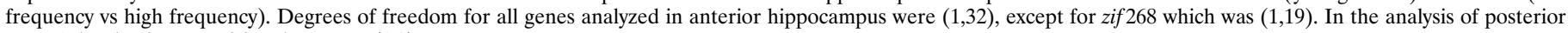
mRNA levels, degrees of freedom were $(1,9)$.

daily LTP stimulation become progressively less robust over a period of days (Abraham et al., 1992), we developed a more temporally condensed stimulus protocol involving multiple repetitions of the patterned activation within a single session. To enhance detection of labile IEG mRNAs, rats were pretreated with the protein synthesis inhibitor cycloheximide, which prolongs the kinetics and increases the levels of IEG mRNAs induced by depolarizing stimulation in brain (Worley et al., 1990).

In pilot studies, we identified a repetitive stimulation protocol that resulted in robust induction of mRNAs for the IEGs zif 268 and jun B (12 repetitions of HF stimulus administered every $15 \mathrm{~min}$; see Materials and Methods). cDNA was prepared from microdissected dorsal and ventral fascia dentata of the hippocampus of control and adult rats after LTP induction and was used to screen replicate Southern blots of a panel of 19 IEGs (Fig. 2B). Duplicate blots were also probed with cDNA from hippocampus of naive control and MECS-stimulated rats (Fig. 2A). Consistent with previous in situ hybridization studies (Worley et al., 1993), zif268 and jun B mRNAs were strongly induced by the LTP-inducing stimulus but not the LF stimulus, which does not produce LTP. Other genes that were also strongly induced by the HF stimulus included krox-20, Rheb, Narp, \#59, Egr-3, jun B, nur 77, and Arc. The inducibility of these genes in the LTP paradigm has been reported previously (see references in Materials and Methods). Note that there is a broad range in the magnitude of the induction between different IEGs, which again replicates observations using conventional Northern and in situ techniques. Blot analyses confirmed that these mRNAs were induced in the dorsal but not the ventral hippocampus (shown graphically in Fig. 4). The restricted distribution of the IEG response to the dorsal hippocampus is characteristic of the LTP paradigm and is distinct from the uniform induction of IEGs in both the ventral and dorsal hippocampus that is seen with a seizure or afterdischarge (Barnes et al., 1994). c-fos mRNA was only weakly induced by the repetitive LTP-inducing stimulation protocol, a characteristic that again distinguishes the response induced by tetanic stimulation from that induced by seizures (compare Fig. 2, $A$ and $B$ ) (Barnes et al., 1994). Moreover, the pattern of multiple IEG induction by the LTP protocol was distinct from that induced by MECS in that many of the IEGs are less strongly induced after LTP than after seizures induced by MECS. These observations confirm that the reverse Northern technique is effective for monitoring mRNA induction in individual hippocampi after HF stimulation.

\section{Comparison of behavioral performance and LTP- induced IEG responses in adult and aged rats}

cDNA was prepared from individual fascia dentata of young adult and old rats after LF $(0.1 \mathrm{~Hz})$ or $\mathrm{HF}(400 \mathrm{~Hz})$ stimuli in the awake, freely behaving state (see Materials and Methods). As observed in previous studies (Gallagher et al., 1993; Shen and Barnes, 1996), the old rats were significantly poorer at learning the location of the hidden platform (Fig. 3). Although both age groups showed improvement over trials $\left(F_{1,19}=8.82 ; p<0.001\right)$, the old rats swam longer, less direct routes to the platform $\left(F_{1,19}\right.$ $=5.47 ; p=0.026)$, and exhibited significantly fewer platform crossings on the probe trial $\left(\chi^{2}=11.59 ; p<0.001\right)$. The performance of the old rats, however, did not differ from that of the young rats when the platform was not submerged and a distinct visual cue was suspended above it $\left(F_{1,19} 0.13 ; p=0.72\right)$, and both young and old rats showed improvement over trials $\left(F_{1,19} 2.68\right.$; $p=0.026)$.

Reverse Northern blots were performed to compare induced IEGs. A qualitative comparison of 10 young rats and 8 aged rats illustrated similar robust inductions of the same IEGs by the HF stimulus in young and old rats (compare Fig. 2, $B$ and $C$ ). This analysis suggested additionally that certain of the IEGs might be induced to different extents in young and aged rats. Accordingly, we performed a quantitative analysis of responses using a phosphorimager. To reduce the complexity of the analysis, we focused on a set of five IEGs that are induced in association with LTP.

Normalized IEG mRNA levels in the anterior two thirds and posterior one third of the hippocampus were subjected to a two-way ANOVA to test the main effects of age (AGE) and stimulation (STIM) and the interaction of AGE $\times$ STIM (Table 1, Fig. 4). In the anterior hippocampus, normalized mRNA levels for c-fos revealed significant effects for AGE and STIM as well as a significant interaction of AGE $\times$ STIM. Similar analyses for jun B, c-jun, and zif268 mRNA levels revealed significant effects of STIM but no significant effects for AGE or AGE $\times$ STIM. Analysis of anterior hippocampal fos $\mathrm{B}$ and fra 1 mRNA levels revealed no significant effects. Similar analysis of posterior hippocampal mRNA levels demonstrated no significant effects for all genes analyzed. Analysis of posterior zif $268 \mathrm{mRNA}$ levels was not conducted because of insufficient sample size.

\section{DISCUSSION}

The present study demonstrates that the IEG response to patterned HF synaptic activity is largely intact in the senescent hippocampus. The stimulation paradigm that we have developed, which combines repetitive stimulation in the presence of protein 

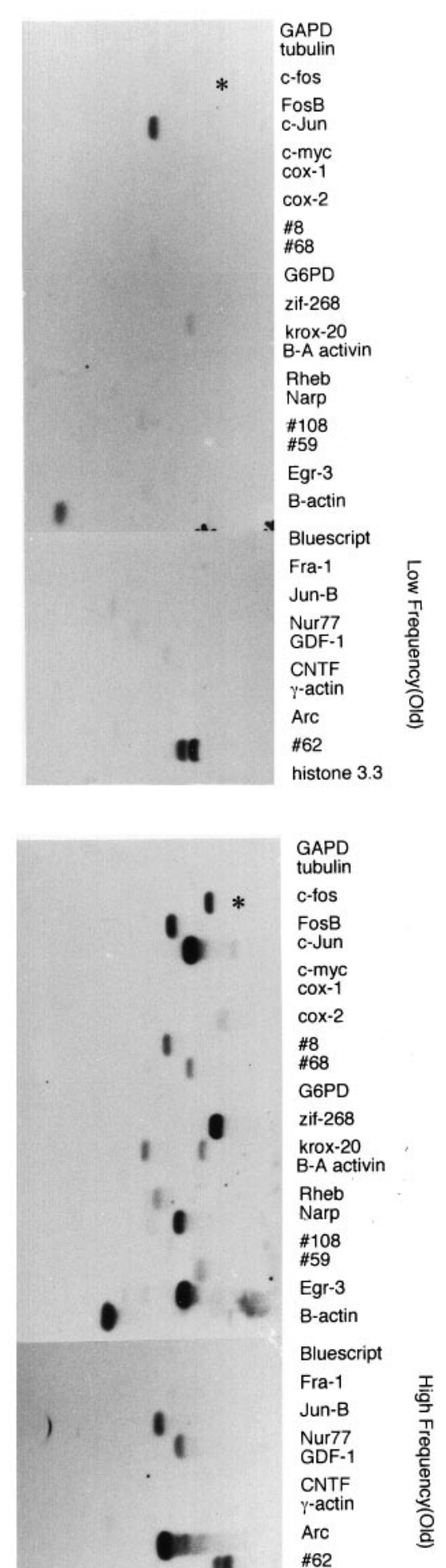

\#62

histone 3.3

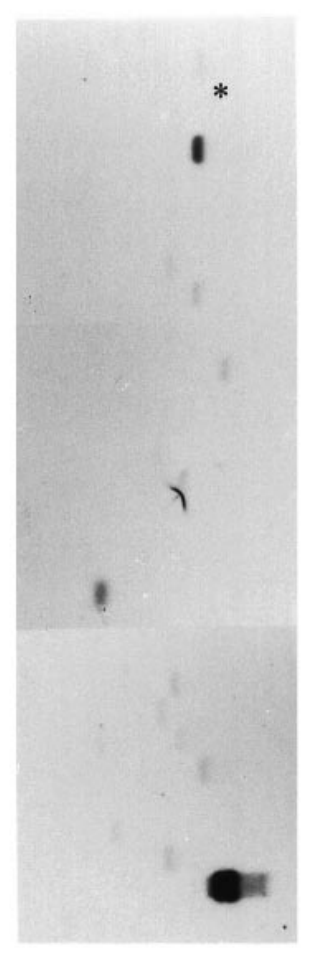

\begin{tabular}{|c|c|}
\hline $\begin{array}{l}\text { GAPD } \\
\text { tubulin }\end{array}$ & \\
\hline c-fos & \\
\hline $\begin{array}{l}\text { FosB } \\
\text { C-Jun }\end{array}$ & \\
\hline $\begin{array}{l}\text { c-myc } \\
\text { cox-1 }\end{array}$ & \\
\hline $\operatorname{cox}-2$ & \\
\hline $\begin{array}{l}\# 8 \\
\# 68\end{array}$ & \\
\hline G6PD & \\
\hline zit-268 & \\
\hline $\begin{array}{l}\text { krox-20 } \\
\text { B-A activin }\end{array}$ & \\
\hline $\begin{array}{l}\text { Rheb } \\
\text { Narp }\end{array}$ & \\
\hline $\begin{array}{l}\# 108 \\
\# 59\end{array}$ & \\
\hline Egr-3 & \\
\hline B-actin & \\
\hline Bluescript & \\
\hline Fra-1 & 5 \\
\hline Jun-B & $\sum$ \\
\hline $\begin{array}{l}\text { Nur77 } \\
\text { GDF-1 }\end{array}$ & $\frac{\vec{\Phi}}{\stackrel{0}{\Phi}}$ \\
\hline $\begin{array}{l}\text { CNTF } \\
\gamma \text {-actin }\end{array}$ & $\stackrel{\frac{D}{2}}{2}$ \\
\hline Arc & 윽 \\
\hline$\# 62$ & ఱ్ \\
\hline
\end{tabular}

histone 3.3
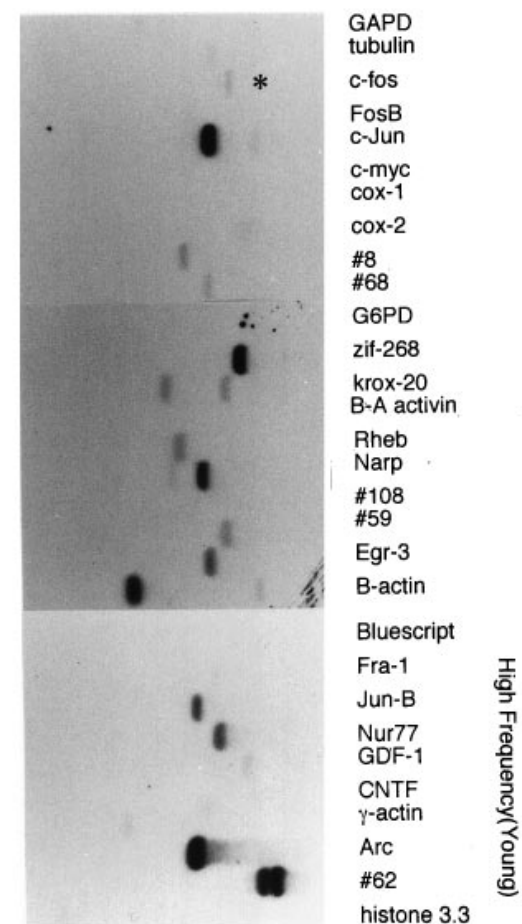

Figure 2. IEG induction by LTP stimulation in adult and aged hippocampus. Cloned cDNA inserts of a panel of IEGs were transferred to nitrocellulose and probed with radiolabeled cDNA prepared from individual hippocampi of naive young controls (top right), MECS-stimulated young controls (bottom right), LF-stimulated young and old rats (middle panels), and HF-stimulated young and old rats (left panels). The HF stimulus induced robust LTP (43 and $45 \%$ population response increase in young and old rats, respectively). Blots presented in the figure are qualitatively representative of the indicated population ( $n=10$ for young LF and HF; $n=8$ for aged LF and HF). Note that MECS induces a robust increase in mRNA levels of nearly all the genes (19 IEGs) in the panel, whereas HF stimulation produces a more selective induction of IEGs in both young and old rats. c-fos mRNA (asterisk) is strongly induced by MECS and by the HF stimulus in aged rats but not young rats. 

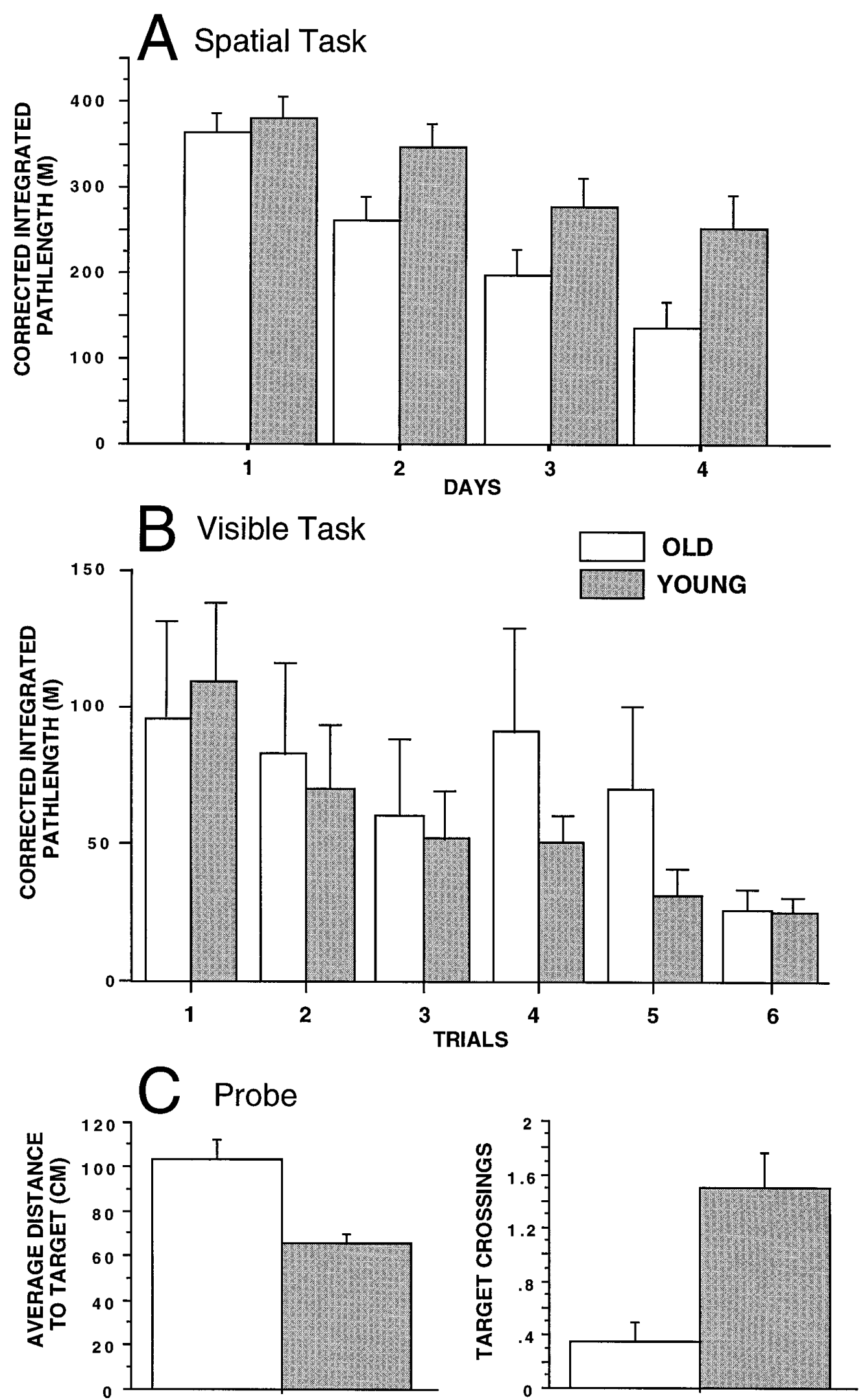

Figure 3. A, Mean \pm SEM corrected integrated path length (CIPL; see Materials and Methods) over $4 \mathrm{~d}$ (six trials per day) of training in the spatial version of the Morris swim task. The old rats took significantly longer paths to find the platform compared with the young rats on days 2,3 , and 4 of training. $B$, Mean \pm SEM CIPL for six training trials on the visual discrimination version of the Morris swim task. There were no statistically significant differences between age groups. $C$, Mean \pm SEM average distance to the target quadrant and target crossings during the spatial probe trial, in which the platform was removed from the pool. The old rats exhibited longer average distances to the target and fewer target crossings than did the young rats, suggesting poorer spatial performance accuracy in the old animals. 
A
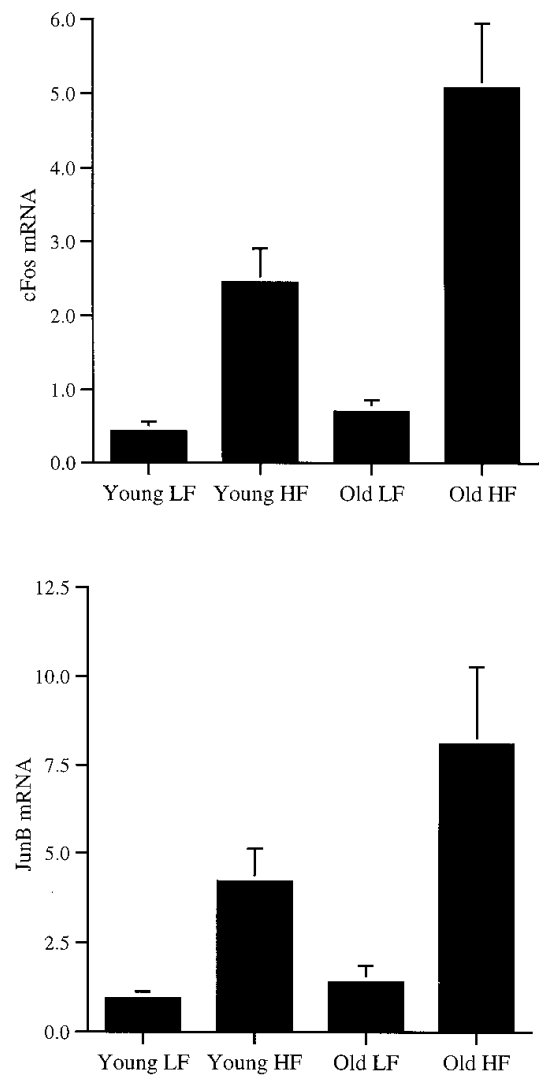

B

Figure 4. Comparison of IEG induction in young and old rats. Histograms comparing normalized (based on GAPD level) mRNA levels in fascia dentata induced by patterned HF stimulation in chronically implanted young adult and aged, memory-impaired rats. Levels of hybridization in low-frequency $(L F)$ - and high-frequency $(H F)$ stimulated fascia dentata were quantitated as described in Materials and Methods. Two-way ANOVA indicates that c-fos mRNA is significantly induced in anterior hippocampus $(A)$ by the HF stimulus in both young and old rats $\left(F_{1,32}=\right.$ 45.246; $p<0.0001$ ), and the induction is greater in the aged animals than in the young adults $\left(F_{1,32}=\right.$ 9.409; $p=0.0044)$. The interaction between age and LTP is also significant $\left(F_{1,32}=6.157 ; p=\right.$ 0.0185 ). zif 268 and jun B were similarly induced by the HF stimulus in young and old rats, whereas Fra-1 was not induced in either young or old rats (for statistics, see Results). As an additional control, we examined c-fos mRNA levels in the posterior one third of the hippocampi $(B)$, in which we demonstrated previously that IEGs are not induced by HF stimulation, using standard electrode placements (Barnes et al., 1994). Consistent with this previous observation, c-fos is not induced in the posterior hippocampus, and there is no difference in levels between young and old rats $(B)$. This indicates that the difference in c-fos induction between young and old rats is anatomically restricted to the region that receives the monosynaptic, patterned stimulus.
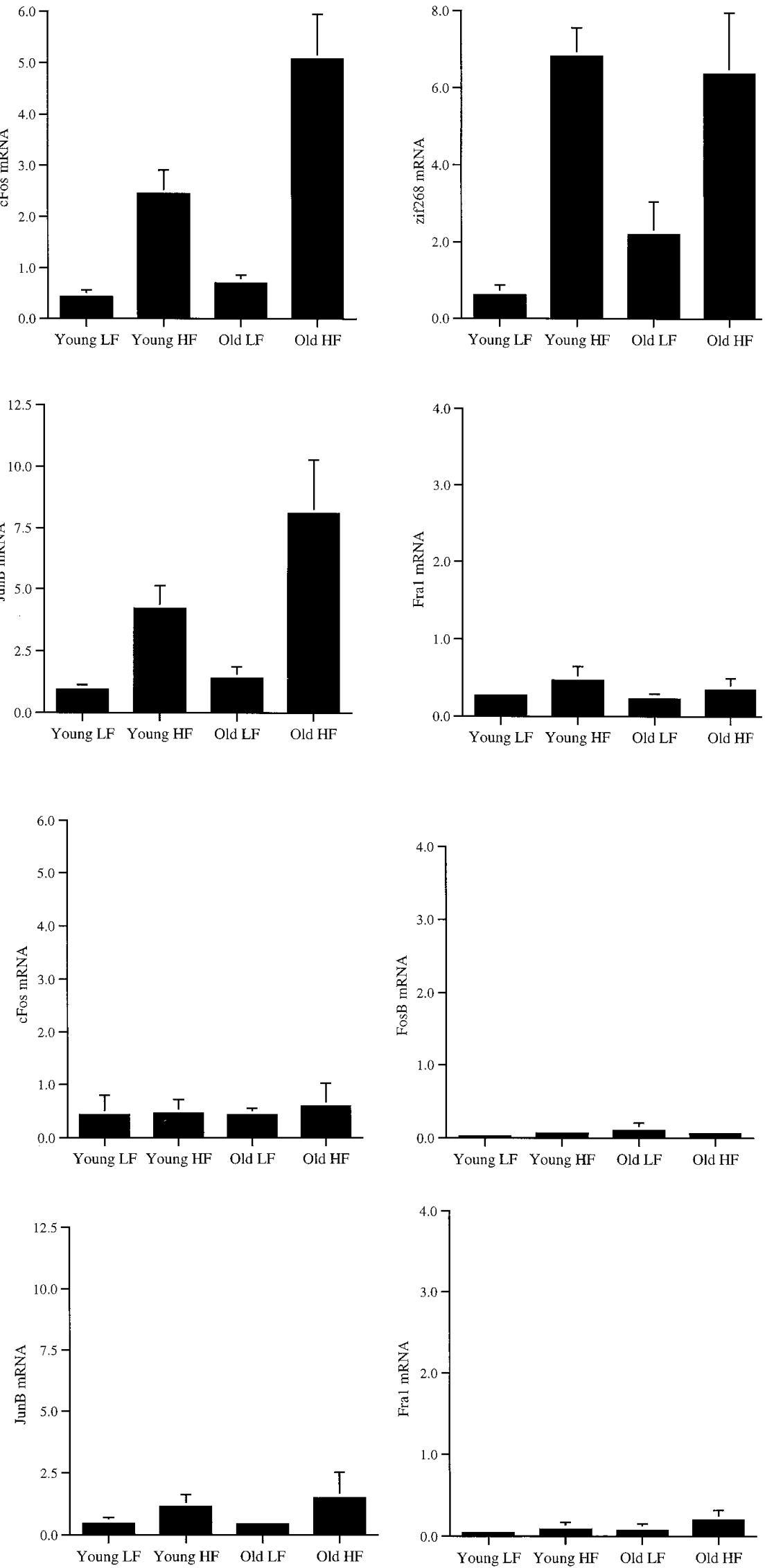
synthesis inhibition, faithfully reproduces the pattern of gene activation seen using conventional in situ and Northern techniques after HF stimulation and boosts levels of induced mRNAs, thereby markedly improving the sensitivity of their detection. Application of the reverse Northern strategy amplifies the number of genes that can be monitored with small tissue samples.

Our survey included a large panel of IEGs and is anticipated to test the functional integrity of signaling and transcriptional mechanisms that control the expression of these genes. We infer that the age-dependent deficit of LTP maintenance is not attributable to a general disruption of these signaling pathways. This result stands in contrast to the reported age-dependent changes in second messenger pathways that are likely be involved in the transduction of extracellular signals into transcriptional responses. For example, aging is associated with reductions in phosphoinositide metabolites and protein kinase $\mathrm{C}$ activation (Martini et al., 1994; Battaini et al., 1995; Undie et al., 1995) as well as with changes in the adenylate cyclase system (Araki et al., 1994) in the rodent brain. It is possible that the various age-dependent changes in enzyme levels represent adaptations that preserve the dynamic signaling function of hippocampal neurons, rather than reflections of primary deficits.

Despite the general conservation of IEG induction in aged rats, quantitative comparisons with adult rats indicate an increase in induced levels of c-fos mRNA in aged animals. c-fos mRNA and protein have been examined previously in aged rodents in response to various stimuli. c-fos is reported to show reduced inducibility in the suprachiasmatic nucleus of aged rats in response to visual stimulation (Sutin et al., 1993). Because there are several synapses that lead from the stimulus to the induced response, it is not certain whether this represents a change in sensory reception or postsynaptic signaling. Induction of c-fos mRNA by pentylenetetrazole seizures is reported to be delayed and significantly reduced relative to young rats (Retchkiman et al., 1996). The age-dependence of pentylenetetrazole metabolism could be important in this paradigm. By contrast, a strength of the monosynaptic LTP induction protocol used in the present experiment is that the presynaptic stimulus intensity can be controlled, and because with the stimulus parameters used here, the induction of LTP is not different between age groups. In fact, when the degree of postsynaptic depolarization is held constant, by pairing intracellular current pulses with afferent stimulation, there is no difference in the LTP induction threshold or magnitude across the life span of the F-344 rat (Barnes et al., 1996). This suggests that immediate receptor-mediated events at the synapse are intact in old rats. Accordingly, the increase in c-fos expression suggests changes in specific signaling pathways involved in either the induction of the mRNA or its turnover.

We have previously demonstrated distinct thresholds for the synaptic activation of different IEGs (Worley et al., 1993). In awake, behaving young adult rats, zif 268 mRNA is strongly induced by patterned synaptic stimuli that are near the threshold for the induction of LTP, whereas c-fos mRNA requires more repetitions of LTP-inducing stimulation. It should be noted that the intensity of the individual stimulus trains was identical for both the treatment that induced only zif 268 and for the one that also induced c-fos mRNA. Furthermore, both responses are completely blocked by previous administration of the NMDA receptor antagonist MK-801. We infer that repetitions of patterned stimulation evoke different signaling events than do individual stimulus trains. This notion is consistent with the observation that in many models of synaptic plasticity, the most enduring forms (which are protein synthesis-dependent) require repeated, spaced stimuli (Goelet et al., 1986; Nguyen et al., 1994). Moreover, activation of the cAMP pathway in hippocampal neurons, which is necessary for establishment of the late phase of LTP, involving calcium/calmodulin, requires repeated spaced stimuli (Frey et al., 1993; Matthies and Reymann, 1993; Blitzer et al., 1995). In the present study, the spacing between repetitions of the HF stimulus was $15 \mathrm{~min}$, which is similar to the spacing typically used to activate the cAMP pathway in hippocampal slices $(5 \mathrm{~min})$. Our studies support the notion that the complex relationship between patterned synaptic activity and activation of signaling pathways may be altered in the aged hippocampus. There is increasing evidence indicating that calcium homeostatic mechanisms are altered in aged brain (Khachaturian, 1984; Landfield et al., 1992; Disterhoft et al., 1996; Hartmann et al., 1996; Landfield, 1996), that calcium action potentials are longer and larger in aged hippocampal neurons (Pitler and Landfield, 1990; Disterhoft et al., 1993), and recently, that there is an increase in the density of L-type $\mathrm{Ca}^{2+}$ channels in aged CA1 neurons (Thibault and Landfield, 1996). Moreover, although the induction of LTP is normal in aged rats, the susceptibility to induction of long-term depression and reversal of LTP are increased with aging (Norris et al., 1996), again consistent with the notion of altered calcium homeostasis. It is possible that such calcium dysregulation modifies the activity of the signaling pathways that result in the observed increase in c-fos induction in old rats.

The transcriptional regulation of c-fos involves multiple regulatory elements and binding proteins, including CRE/CREB, AP-1, SIE/SIF (p91), and SRE/SRE binding protein (Treisman, 1985; Sheng et al., 1988; Schönthal et al., 1989; Wagner et al., 1990; Bading et al., 1993; Meyer et al., 1993; Robertson et al., 1995). Greenberg and co-workers demonstrated that c-fos is induced in hippocampal neurons by two distinct, calcium-dependent pathways that use SRE or CRE binding proteins and that are preferentially activated by calcium entry through NMDA receptor and L-type calcium channels, respectively (Meyer et al., 1993). Moreover, the NMDA receptor-regulated SRF-dependent pathway operates in concert with the transcription factor Elk-1, which in turn requires phosphorylation by extracellular signal-regulated kinases (Xia et al., 1996). Details of these complex signaling pathways remain to be established. Studies of the cellular basis of age-dependent growth arrest using human diploid fibroblasts (HDFs) have also documented selective changes in the inducibility of c-fos (for review, see Stein and Vjekoslov, 1995). In response to serum, senescent HDFs fail to increase expression of c-fos, but show normal induction of c-myc, c-jun, and jun B compared with low-passage quiescent cells (Seshadri and Campisi, 1990; Riabowol et al., 1992). Age-dependent changes in signal transduction pathways in senescent fibroblasts that may contribute to the c-fos induction deficit include hyperphosphorylation of SRF, associated with a decrease in its ability to bind to the serum response element (Atadja et al., 1994), evidence of reduced activation of protein kinase C (DeTata et al., 1993; Venable et al., 1994), and altered phosphorylation and presumptive activation of MAP kinase (Afshari et al., 1993) in response to serum. Because similar mechanisms are likely to be involved in the regulation of c-fos in brain, some of these same processes may be involved in the altered c-fos regulation observed in old hippocampal neurons in the present experiment.

The present study provides an assay of a dynamic function of the hippocampus that is relevant to age-dependent memory decline and focuses attention on specific cellular mechanisms that 
regulate the response of c-fos. One caveat regarding the reverse Northern strategy, in its present use, is that it lacks cellular resolution, and it remains to be determined whether agedependent changes in gene expression after the LTP-inducing stimulus are uniquely associated with neurons. It has recently become possible to assay mRNA in single neurons (Crino and Eberwine, 1996), which together with refinements in the analysis of differential gene expression (Schena et al., 1995) should permit more detailed analyses of cellular changes in induced gene expression in aging. Microarray DNA blotting techniques can potentially examine the regulation of thousands of candidate genes. Such an analysis not only provides the opportunity to target mechanisms that contribute to age-dependent cognitive decline but also should lead to a better understanding of the mechanisms involved in durable plastic changes in organisms of all ages.

\section{REFERENCES}

Abraham WC, Dragunow M, Tate WP (1992) The role of immediate early genes in the stabilization of long-term potentiation. Mol Neurobiol 5:297-314.

Afshari CA, Vojta PJ, Annab LA, Futreal PA, Willard TB, Barrett JC (1993) Investigation of the role of G1/S cell cycle mediators in cellular senescence. Exp Cell Res 209:231-237.

Agranoff B (1981) Learning and memory: biochemical approaches. In: Basic Neurochemistry, 3rd Ed (Siegel G, Albers R, Agranoff B, Katzman R, eds), pp 801-820. Boston: Little Brown and Company.

Ammendola R, Mesuraca M, Russo T, Cimino F (1992) Sp1 DNA binding efficiency is highly reduced in nuclear extracts from aged rat tissues. J Biol Chem 267:17944-17948.

Andreasson K, Worley P (1995) Induction of $\beta$-A activin expression by synaptic activity and during neocortical development. Neuroscience 69:781-796.

Araki T, Kato H, Kanai Y, Kogure K (1994) Age-dependent changes in second messenger and rolipram receptor systems in the gerbil brain. J Neural Transm Gen Sect 97:135-147.

Atadja PW, Stringer KF, Riabowol KT (1994) Loss of serum response element-binding activity and hyperphosphorylation of serum response factor during cellular aging. Mol Cell Biol 14:4991-4999.

Bading H, Ginty DD, Greenberg ME (1993) Regulation of gene expression in hippocampal neurons by distinct calcium signaling pathways. Science 260:181-186.

Barnes CA (1979) Memory deficits associated with senescence: a neurophysiological and behavioral study in the rat. J Comp Physiol Psychol 931:74-104.

Barnes CA, McNaughton BL (1980) Spatial memory and hippocampal synaptic plasticity in middle-aged and senescent rats. In: Psychobiology of aging: problems and perspectives (Stein D, ed), pp 253-272. New York: Elsevier/North-Holland.

Barnes CA, McNaughton BL (1985) An age comparison of the rates of acquisition and forgetting of spatial information in relation to long-term enhancement of hippocampal synapses. Behav Neurosci 99:1040-1048.

Barnes CA, Jung MW, McNaughton BL, Korol DK, Andreasson K, Worley PF (1994) LTP saturation and spatial learning disruption: effects of task variables and saturation levels. J Neurosci 14:5793-5806.

Barnes CA, Rao G, McNaughton BL (1996) Functional integrity of NMDA-dependent LTP induction mechanisms across the lifespan of F344 rats. Learn Memory 3:124-137.

Battaini F, Elkabes S, Bergamaschi S, Ladisa V, Lucchi L, De Graan PN, Schuurman T, Wetsel WC, Trabucchi M, Govoni S (1995) Protein kinase $\mathrm{C}$ activity, translocation, and conventional isoforms in aging rat brain. Neurobiol Aging 16:137-148.

Bliss TVP, Lomo T (1973) Long-lasting potentiation of synaptic transmission in the dentate area of the anaesthetised rabbit following stimulation of perforant path. J Physiol (Lond) 232:331-356.

Blitzer RD, Wong T, Nouranifar R, Iyengar R, Landau EM (1995) Postsynaptic cAMP pathway gates early LTP in hippocampal CA1 region. Neuron 15:1403-1414.

Cole A, Saffen D, Baraban J, Worley P (1989) Rapid increase of an immediate early gene mRNA in hippocampal neurons by synaptic NMDA receptor activation. Nature 340:474-476.

Crino PB, Eberwine J (1996) Molecular characterization of the dendritic growth cone: regulated mRNA transport and local protein synthesis. Neuron 17:1173-1187.

Davis HP, Squire LR (1984) Protein synthesis and memory: a review. Physiol Bull 96:518-559.

DeTata VA, Ptasznik A, Cristofalo VJ (1993) Effect of the tumor promotor phorbol 12-myristate 13-acetate (PMA) on proliferation of young and senescent WI-38 human diploid fibroblasts. Exp Cell Res 205:261-269.

de Toledo-Morrell L, Geinisman Y, Morrell F (1988) Age-dependent alterations in hippocampal synaptic plasticity: relation to memory disorders. Neurobiol Aging 9:581-590.

Deupree DL, Turner DA, Watter CL (1991) Spatial performance correlates with in vitro potentiation in young and aged Fischer 344 rats. Brain Res 554:1-9.

Disterhoft HF, Moyer Jr JR, Thompson LT, Kowalska M (1993) Functional aspects of calcium-channel modulation. Clin Neuropharmacol 16:S12-S24.

Disterhoft JF, Thompson LT, Moyer JR, Mogul DJ (1996) Calciumdependent afterhyperpolarization and learning in young and aging hippocampus. Life Sci 59:413-420.

Douglas R, Dragunow M, Robertson H (1988) High-frequency discharge of dentate granule cells, but no long-term potentiation, induces c-fos protein. Mol Brain Res 4:259-262.

Dragunow M, Abraham WC, Goulding M, Mason SE, Robertson HA, Faull RLM (1989) Long-term potentiation and the induction of c-fos mRNA and proteins in the dentate gyrus of unanesthetized rats. Neurosci Lett 101:274-280.

Flexner JB, Flexner LB, Stellar E (1963) Memory in mice as affected by intracerebral puromycin. Science 141:57-59.

Frey U, Huang YY, Kandel ER (1993) Effects of cAMP simulate a late stage of LTP in hippocampal CA1 neurons. Science 260:1661-1664.

Gall C, Lauterborn J (1992) The dentate gyrus: a model system for studies of neurotrophin regulation. Epilepsy Res [Suppl] 7:171-185.

Gallagher M, Burwell R, Burchinal M (1993) Severity of spatial learning impairment in aging: development of a learning index for performance in the Morris water maze. Behav Neurosci 107:618-626.

Goelet P, Castellucci V, Schacher S, Kandel E (1986) The long and the short of long-term memory: a molecular framework. Nature 322:419-422.

Hartmann H, Eckert A, Velbinger K, Rewsin M, Muller WE (1996) Down-regulation of free intracellular calcium in dissociated brain cells of aged mice and rats. Life Sci 59:435-449.

Hori N, Hirotsu I, Davis PJ, Carpenter DO (1992) Long-term potentiation is lost in aged rats but preserved by calorie restriction. NeuroReport 3:1085-1088.

Khachaturian ZS (1984) Towards theories of brain aging. In: Handbook of studies on psychiatry and old age (D Kay, GD Burrows, eds), pp 7-30. Amsterdam: Elsevier.

Lanahan A, Williams JB, Sanders LK, Nathans D (1992) Growth factorinduced delayed early response genes. Mol Cell Biol 12:3919-3929.

Landfield PW (1996) Aging-related increase in hippocampal calcium channels. Life Sci 59:399-404.

Landfield PW, Lynch G (1977) Impaired monosynaptic potentiation of in vitro hippocampal slices from aged, memory deficient rats. J Gerontol 32:523-533.

Landfield PW, McGaugh JL, Lynch G (1978) Impaired synaptic potentiation process in the hippocampus of aged, memory deficient rats. Brain Res 150:85-101.

Landfield PW, Thibault O, Mazzanti ML, Porter NM, Kerr S (1992) Mechanisms of neuronal death in brain aging and Alzheimer's disease: role of endocrine-mediated calcium dyshomeostasis. J Neurobiol 23:1247-1260.

Lyford G, Yamagata K, Kaufmann WE, Barnes CA, Sanders LK, Copeland NG, Gilbert DJ, Jenkins NA, Lanahan AA, Worley PF (1995) Arc, a growth factor and activity-regulated gene encodes a novel cytoskeleton-associated protein that is enriched in neuronal dendrites. Neuron 14:433-445.

Lynch MA, Voss KL (1994) Membranc arachidonic acid concentratiion correlates with age and induction of long-term potentiation in the dentate gyrus of the rat. Eur J Neurosci 6:1008-1014.

Martini A, Battaini F, Govoni S, Volpe P (1994) Inositol 1,4,5trisphosphate receptor and ryanodine receptor in the aging brain of Wistar rats. Neurobiol Aging 15:203-206.

Matthies H, Reymann KG (1993) Protein kinase A inhibitors prevent the 
maintenance of hippocampal long-term potentiation. NeuroReport 4:712-714.

Meyer DJ, Stephenson EW, Johnson L, Cochran BH, Schwartz J (1993) The serum response element can mediate induction of c-fos by growth hormone. Proc Natl Acad Sci USA 90:6721-6725.

Montarolo PG, Goelet P, Castellucci V, Morgan J, Kandel E, Schacher S (1986) A critical period for macromolecular synthesis in long-term heterosynaptic facilitation in Aplysia. Science 234:1249-1254.

Moore CI, Browning MD, Rose GM (1993) Hippocampal plasticity induced by primed burst, but not long-term potentiation, stimulation is impaired in area CA1 of aged Fischer 344 rats. Hippocampus 3:57-66.

Morgan J, Cohen D, Hempstead J, Curran T (1987) Mapping patterns of c-fos expression in the central nervous system after seizure. Science 237:192-197.

Morris RGM (1981) Spatial localization does not require the presence of local cues. Learn Motiv 12:239-261.

Norris CM, Korol DL, Foster TC (1996) Increased susceptibility to induction of long-term depression and long-term potentiation reversal during aging. J Neurosci 16:5382-5392.

Nguyen PV, Abel T, Kandel ER (1994) Requirement of a critical period of transcription for induction of a late phase of LTP. Science 265:1104-1107.

Pitler TA, Landfield PW (1990) Aging-related prolongation of calcium spike duration in rat hippocampal slice neurons. Brain Res 508:1-6.

Qian Z, Gilbert ME, Colicos MA, Kandel ER, Kuhl D (1993) Tissueplasminogen activator is induced as an immediate-early gene during seizure, kindling and long-term potentiation. Nature 361:453-457.

Retchkiman I, Fischer B, Platt D, Wagner AP (1996) Seizure induced c-fos mRNA in the rat brain: comparison between young and aging animals. Neurobiol Aging 17:41-44.

Riabowol K, Schiff J, Gilman MZ (1992) Transcription factor AP-1 activity is required for initiation of DNA synthesis and is lost during cellular aging. Proc Natl Acad Sci USA 89:157-161.

Robertson LM, Kerppola TK, Vendrell M, Luk D, Smeyne RJ, Bocchiaro C, Morgan JI, Curran T (1995) Regulation of c-fos expression in transgenic mice requires multiple interdependent transcription control elements. Neuron 14:241-252.

Saffen DW, Cole AJ, Worley PF, Christy BA, Ryder K, Baraban JM (1988) Convulsant-induced increase in transcription factor messenger RNAs in rat brain. Proc Natl Acad Sci USA 85:7795-7799.

Schena M, Shalon D, Davis RW, Brown PO (1995) Quantitative monitoring of gene expression patterns with a complementary DNA microarray. Science 270:467-470.

Schönthal A, Büscher M, Angel P, Rahmsdorf HJ, Ponta H, Haqori K, Chiu R, Karin M, Herrlich P (1989) The Fos and Jun/AP-1 proteins are involved in the downregulation of Fos transcription. Oncogene 4:629-636.

Seshadri T, Campisi J (1990) Repression of c-fos transcription and an altered genetic program in senescent human fibroblasts. Science 247:205-209.

Shen J, Barnes CA (1996) Age-related decrease in cholinergic synaptic transmission in three hippocampal subfields. Neurobiol Aging 17:439-451.

Sheng M, Dougan ST, McFadden G, Greenberg ME (1988) Calcium and growth factor pathways of c-fos transcriptional activation require distinct upstream regulatory sequences. Mol Cell Biol 8:2787-2796.

Stein GH, Vjekoslov D (1995) Origins of G1 arrest in senescent human fibroblasts. BioEssays 17:537-543.
Supakar PC, Song CS, Jung MH, Slomczynska MA, Kim J-M, Vellanoweth RL, Chatterjee B, Roy AK (1993) A novel regulatory element associated with age-dependent expression of the rat androgen receptor gene. J Biol Chem 268:26400-26408.

Sutin EL, Dement WC, Heller HC, Kilduff TS (1993) Light-induced gene expression in the suprachiasmatic nucleus of young and aging rats. Neurobiol Aging 14:441-446.

Thibault O, Landfield PW (1996) Increase in single L-type calcium channels in hippocampal neurons during aging. Science 272:1017-1020.

Thoenen H (1995) Neurotrophins and neuronal plasticity. Science 270:593-598.

Tielen AM, Mollevanger WJ, Lopes da Silva FH, Hollander CF (1983) Neuronal plasticity in hippocampal slices of extremely old rats. In: Aging of the brain (Gispen WH, Traber J, eds), pp 73-84. New York: Elsevier.

Treisman R (1985) Transient accumulation of c-fos RNA following serum stimulation requires a conserved 5' element and c-fos 3 ' sequences. Cell 42:889-902.

Tsui C, Copeland NG, Gilbert DJ, Jenkins NA, Barnes CA, Worley PF (1996) Narp, a novel member of the pentraxin family, promotes neurite outgrowth and is dynamically regulated by neuronal activity. $\mathrm{J}$ Neurosci 16:2463-2478.

Tully T, Preat T, Boynton SC, Vecchio D (1994) Genetic dissection of consolidated memory in Drosophila. Cell 79:35-47.

Undie AS, Wang HY, Friedman E (1995) Decreased phospholipase C-beta immunoreactivity, phosphoinositide metabolism, and protein kinase $\mathrm{C}$ activation in senescent F-344 rat brain. Neurobiol Aging 16:19-28.

Venable ME, Blobe GC, Odeid LM (1994) Identification of a defect in the phospholipase $\mathrm{D} /$ diacylglycerol pathway in cellular senescence. J Biol Chem 269:26040-26044.

Wagner BJ, Hayes TE, Hoban CJ, Cochran BH (1990) The SIF binding element confers sis/PDGF inducibility onto the c-fos promoter. EMBO J 9:4477-4484.

Worley PF, Cole AJ, Murphy TM, Christy BA, Nakabeppu Y, Baraban JM (1990) Synaptic regulation of immediate early genes in brain. Cold Spring Harbor Symp Quant Biol 55:213-223.

Worley PF, Bhat RV, Baraban JM, Erickson CA, McNaughton BL, Barnes CA (1993) Thresholds for synaptic activation of transcription factors in hippocampus: correlation with long-term enhancement. J Neurosci 13:4776-4786.

Xia Z, Dudek H, Miranti CK, Greenberg M (1996) Calcium influx via the NMDA receptor induces immediate early gene transcription by a MAP kinase/ERK-dependent mechanism. J Neurosci 16:5425-5436.

Yamagata K, Andreasson KI, Kaufmann WE, Barnes CA, Worley PF (1993) Expression of a mitogen-inducible cyclooxygenase in brain neurons: regulation by synaptic activity and glucocorticoids. Neuron 11:371-386.

Yamagata K, Kaufmann WE, Lanahan A, Papapavlou M, Barnes CA, Worley PF (1994a) Egr3/Pilot, a zinc-finger transcription factor, is rapidly regulated by activity in brain neurons and co-localizes with E.g.r1/ Zif268. Learn Memory 1:140-152.

Yamagata K, Sanders LK, Kaufmann WE, Barnes CA, Nathans D, Worley PF (1994b) Rheb, a growth factor and synaptic activity regulated gene, encodes a novel Ras-related protein. J Biol Chem 269:16333-16339. 